Review Article

\title{
Biochar Preparation, Characterization, and Adsorptive Capacity and Its Effect on Bioavailability of Contaminants: An Overview
}

\author{
Obemah D. Nartey and Baowei Zhao \\ School of Environmental and Municipal Engineering, Lanzhou Jiaotong University, Lanzhou 730070, China \\ Correspondence should be addressed to Baowei Zhao; baoweizhao@mail.lzjtu.cn
}

Received 15 April 2014; Revised 22 July 2014; Accepted 24 July 2014; Published 27 October 2014

Academic Editor: Wei Zhou

Copyright ( 2014 O. D. Nartey and B. Zhao. This is an open access article distributed under the Creative Commons Attribution License, which permits unrestricted use, distribution, and reproduction in any medium, provided the original work is properly cited.

\begin{abstract}
This paper provides an updated review on the subjects, the available alternative to produce biochar from biomass, quantification and characterization of biochar, the adsorptive capacity for the adsorption of contaminants, and the effect of biochar addition to agricultural soils on contaminant bioavailability. The property of biochar produced is much dependent upon the composition and type of biomass and the conditions at which biomass is carbonized. The physical and chemical characterizations are necessary to identify the basic structure and property of biochar and to predict its potential in various environmental application. Biochar is a promising alternative to remedy the soils contaminated with heavy metals and organic compounds through adsorption and immobilization due to its large surface area, charged surface, and functional groups. Overall, the bioavailability of heavy metals and organic compounds decreases when biochar is amended into soils.
\end{abstract}

\section{Introduction}

Biochar $(\mathrm{BC})$ is the carbon-rich product obtained when biomass, such as wood, manure, or leaves, is heated in a closed container with little or no available air. In more technical terms, $\mathrm{BC}$ is produced by so-called thermal decomposition of organic material under limited supply of oxygen $\left(\mathrm{O}_{2}\right)$ and at relatively low temperature $\left(<700^{\circ} \mathrm{C}\right)$ [1]. The term "BC" is a relatively contemporary development, evolving in conjunction with soil management, carbon sequestration issues, and immobilization of pollutants [2].

Addition of $\mathrm{BC}$ to agriculture soils has been projected as a means to improve soil fertility and mitigate climate change [3-7]. Recently, it is reported that conversion of biomass into $\mathrm{BC}$ can not only result in the renewable energy (synthetic gas and biooil), but also decrease the content of $\mathrm{CO}_{2}$ in the atmosphere, which reveal more research on the effect and behaviour of $\mathrm{BC}$ in soil [8-11]. It is indicated that amending $\mathrm{BC}$ into soil improves the structure and properties of soil, such as the water-holding capacity, organic matter content, aeration condition, $\mathrm{pH}$ value, cationic exchange capacity (CEC), and the formation of aggregates of soil [7, 12-15]. The leaching losses of nitrogen and phosphorous in soil and the releases of greenhouse gases $\left(\mathrm{N}_{2} \mathrm{O}\right.$ and $\left.\mathrm{CH}_{4}\right)$ from soil could be decreased in the presence of $\mathrm{BC}[4-6,16]$. In addition, $\mathrm{BC}$ has porous structure, charged surface, and surface functional groups (such as carboxyl, hydroxyl, phenolic hydroxyl, and carbonyl groups). These properties are the important factors that influence the migration, transformation, and bioavailability of contaminants in soil.

Figure 1 shows a schematic process diagram for the factors affecting $\mathrm{BC}$ production and application. This paper reviews the literature available for the production of $\mathrm{BC}$ from different category of biomasses, quantification and characterization of the resultant BC, adsorptive capacity, and the progresses made on experimental work and the importance in the environment.

\section{Production of BC}

2.1. Category of Biomasses. BCs are made from range of biomasses that have different chemical and physical properties. The properties of each biomass feedstock are important in thermal conversion processes, particularly the proximate analysis (ash and moisture content), caloric value, fractions 


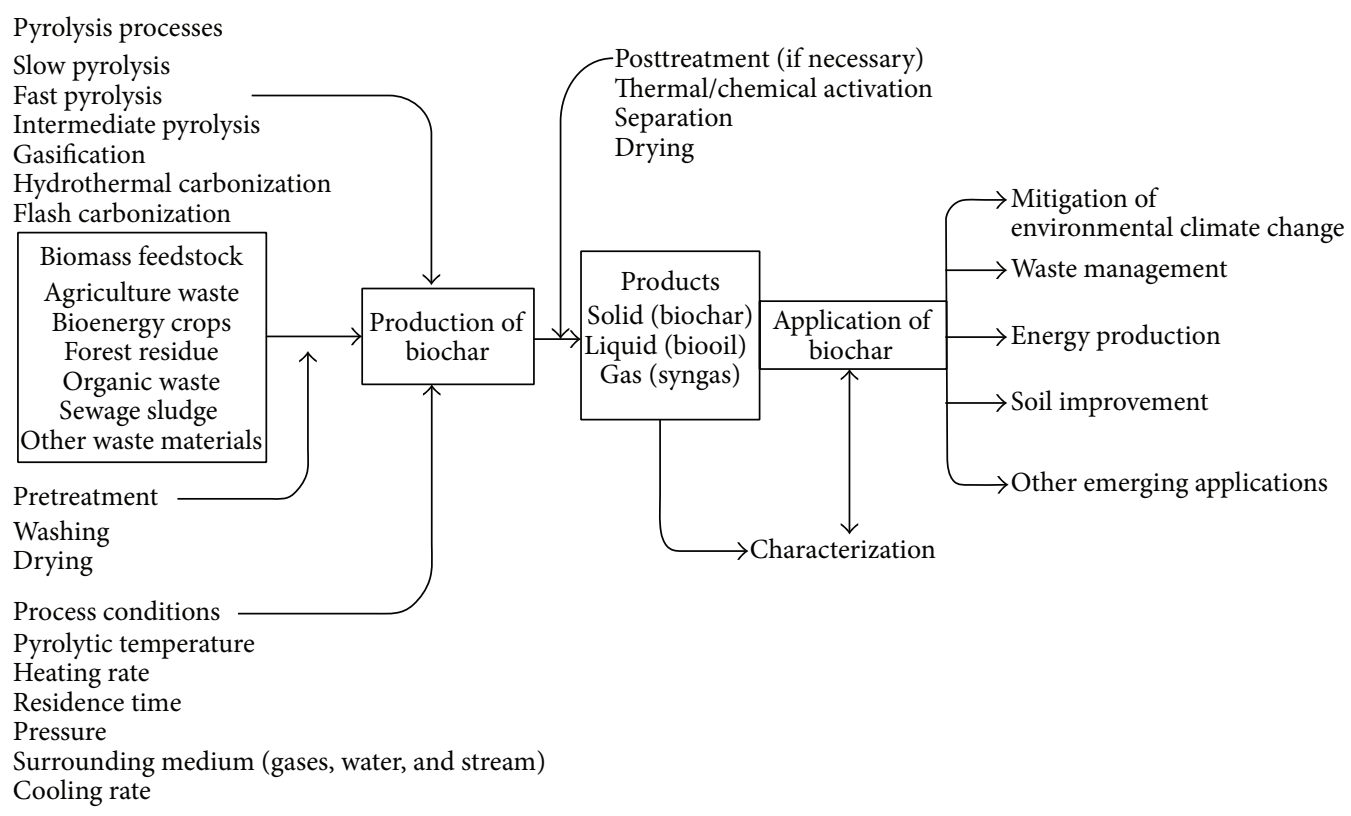

FIGURE 1: Schematic process diagram for the factors affecting BC production and application.

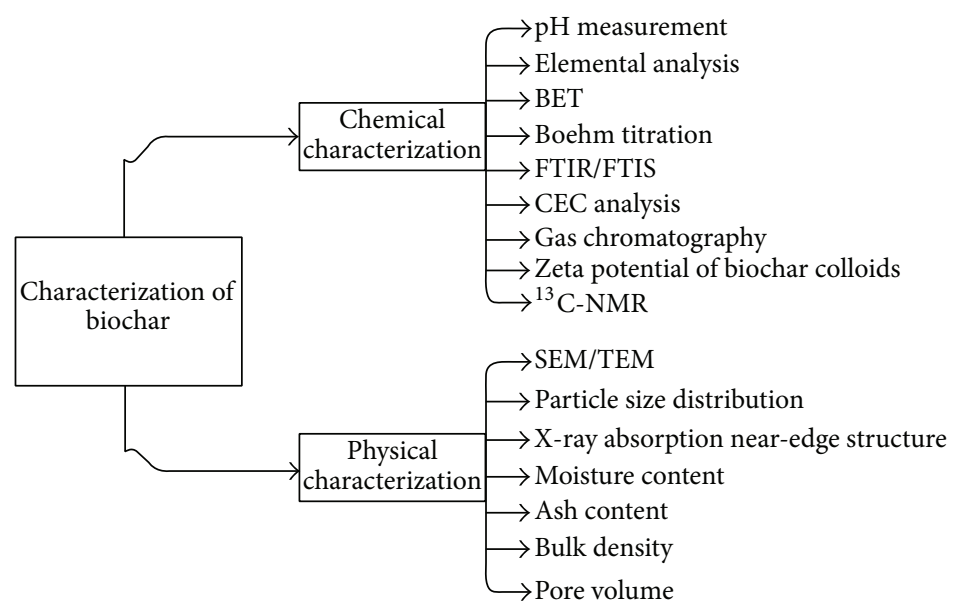

FIGURE 2: Overview of proposed characterization of BC.

of fixed carbon, and volatile components [17]; percentage of lignin, cellulose, and hemicelluloses [18]; percentage and composition of inorganic substance, bulk, true density, particle size, and moisture content. Extensive feedstock biomasses have been used in the production of BC [17], such as bioenergy crops (willows, miscanthus, and switchgrass) [19, 20], forest residues (sawdust, grain crops, and nut shells) [21], organic waste (green yard waste and animal manure) [22, 23], agricultural waste [24-29], kitchen waste, and sewage sludge [30]. It was again found that the following temperaturedependent structure transition was proposed: (1) transition BC having crystalline nature of the biomass feedstock or material preserved; (2) amorphous BC that is a random mixture of thermally changed molecules and emerging aromatic polycondensates; (3) composite BCs having poorly structured graphene stacks fixed in their amorphous phase; and (4) turbastic BC dominated by chaotic graphite crystallites [31]. In general, a high yield of $\mathrm{BC}$ derived from this biomass which has more lignin and less cellulose can be expected. Meanwhile, the porosity of BC increases with the content of lignin in biomass. In addition, the volatile component, water content, and particle size and shape of biomass will affect the property of BC obtained. BCs formed at higher temperatures (lower oxygen to carbon ratio) are expected to be $\pi$-donors, while BCs formed at lower temperatures are expected to be $\pi$-acceptors [32]. BC produced from agricultural waste biomasses does not cause any notable life cycle based greenhouse gas (GHG) emissions [33].

2.2. Preparation of $B C$. Carbonised organic matter can essentially have different physical and chemical properties based on the technology (e.g., torrefaction (a pyrolytic 

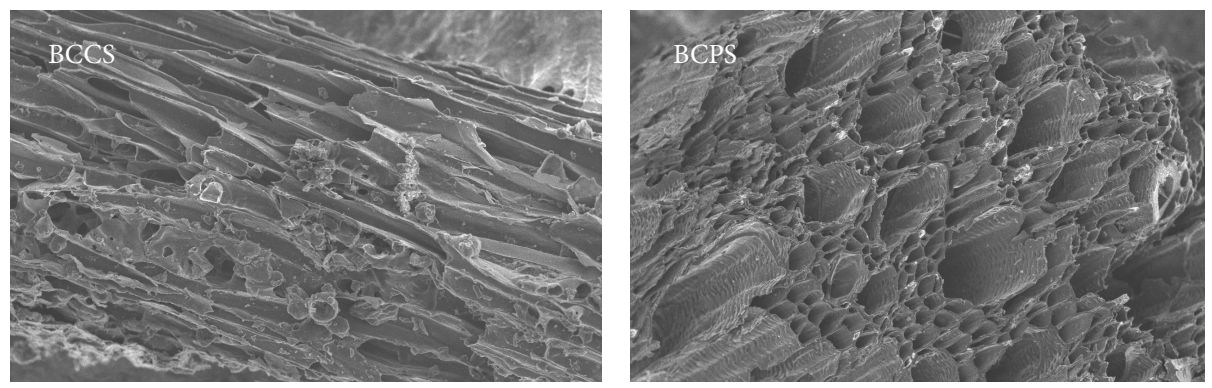

Figure 3: Photomicrograph from SEM.

TABLE 1: Biomass feedstock products of different types of pyrolysis.

\begin{tabular}{|c|c|c|c|}
\hline Process & $\begin{array}{c}\text { Liquid } \\
\text { (biooil) } \\
(\%)\end{array}$ & $\begin{array}{c}\text { Solid } \\
(\mathrm{BC}) \\
(\%) \\
\end{array}$ & $\begin{array}{c}\text { Gas } \\
\text { (syngas) } \\
(\%)\end{array}$ \\
\hline Fast pyrolysis: moderate temperature $\left(600^{\circ} \mathrm{C}\right)$, short hot vapour residence time & 75 & 12 & 13 \\
\hline Intermediate pyrolysis: low moderate temperature, moderate hot vapour residence time & 50 & 25 & 25 \\
\hline Slow pyrolysis: low moderate temperature, long residence time & 30 & 35 & 35 \\
\hline Gasification: high temperature $\left(>700^{\circ} \mathrm{C}\right)$, long vapour residence time & 5 & 10 & 85 \\
\hline Hydrothermal carbonization: elevated temperature $\left(200-250^{\circ} \mathrm{C}\right)$ and elevated pressure. & NRA & NRA & NRA \\
\hline Flash carbonization: $\left(350-650^{\circ} \mathrm{C}\right)$, residence time below 30 minutes, at elevated pressure $(1-3 \mathrm{MPa})$ & NRA & 50 & 50 \\
\hline
\end{tabular}

${ }^{*} \mathrm{NAR}=$ not readily available.

process primarily at low temperature), slow pyrolysis, intermediate pyrolysis, fast pyrolysis, gasification, hydrothermal carbonization (HTC), or flash carbonization) used for its production [34]. In contrast to considerable research, this has already been carried out to assess the value of BC as soil amendment [35]. No publication was identified which looks at the use of BCs from modern pyrolysis as soil amendment and immobilization of both inorganic and organic contaminants in the soil and water systems. BC can be produced both in traditional earthen charcoal kilns, where pyrolysis, gasification, and combustion process are carried out in parallel below the earthen kiln layer, and in modern $\mathrm{BC}$ retorts, where pyrolysis and combustion processes are physically separated by a metal barrier [36]. Papers have been published on the suitability of BC for the stabilization of organic carbon [3] and on the suitability of BC for the improvement of soil properties and immobilization of contaminants in both soil and solution systems [37].

Pyrolysis technology can be distinguished by the residence time, pyrolytic temperature of the pyrolysis material (e.g., slow and fast pyrolysis process), pressure, size of adsorbent, and the heating rate and method (e.g., pyrolysis started by the burning of fuels, by electrical heating, or by microwaves). Asensio et al. and IEA Bioenergy differentiate pyrolysis technology according to the pyrolytic temperature and the residence time of the pyrolysis or carbonization process as can be seen from Table $1[36,38]$.

Slow pyrolysis (heating for seconds or minutes) may be described as a continuous process, where purged (oxygenfree) feedstock biomass is transferred into an external heated kiln or furnace (gas flow removing volatile BC emerging at the other end); "fast" pyrolysis on the other hand depends on very quick heat transfer, typically to fine biomass particles at less than $650^{\circ} \mathrm{C}$ with rapid heating rate $\left(\mathrm{ca} 100-1000^{\circ} \mathrm{C} / \mathrm{s}\right.$ ) [39]. The characteristics of the BC product are heavily affected by the extent of pyrolysis (pyrolytic temperature and residence pressure) and entirely by biomass size and kiln or furnace residence time [36]. The rate at which volatile and gases are removed in a kiln or furnace determines the vapour residence time [39]. Prolonged residence time results in secondary reactions, notably the reactions of tar on BC surfaces and charring of the tar rather than additional combustion or processing outside the kiln or furnace [40]. For gasification in pyrolysis, the biomass feedstock to some extent is oxidized in the gasification chamber at a temperature of about $800^{\circ} \mathrm{C}$ at atmospheric or elevated pressure $[40,41]$. As already pointed out by its name, the main product of this process is gas; only few or no BCs, liquids, or the likes are formed.

The hydrothermal carbonization of biomass is obtained by applying high pyrolytic temperature $\left(200-250^{\circ} \mathrm{C}\right)$ to a biomass in a suspension with liquid under high atmospheric pressure for several hours. It yields solid, liquid, and gaseous products [42]. Libra et al. refer to hydrothermal carbonization as a "wet pyrolysis" [43]. Because no oxygen is applied to the reactor with the biomass liquid suspension, this explanation is readily accepted.

On the other hand, with flash carbonization of biomass, a flash fire is lights up at an elevated pressure (at about 1$3 \mathrm{MPa}$ ) at the underneath of a packed bed biomass. The fire travels in an upward direction through the carbonization bed against the downward flow of air supplied to the process. A total of about $0.8-1.5 \mathrm{~kg}$ of air per $\mathrm{kg}$ of biomass is injected 
TABLE 2: List of some notable chemical characterizations of BC.

\begin{tabular}{|c|c|c|c|}
\hline Characterization & Determination & Results and remarks & References \\
\hline $\begin{array}{l}\text { Elemental } \\
\text { analysis }\end{array}$ & $\mathrm{C}, \mathrm{H}, \mathrm{O}, \mathrm{S}$, and $\mathrm{N}$ associated ratios & $\begin{array}{l}\mathrm{H} / \mathrm{C}, \mathrm{O} / \mathrm{C} \text {, and } \mathrm{N} \text { associated ratios are used to } \\
\text { determine the degree of aromaticity and maturation }\end{array}$ & {$[56,60,61]$} \\
\hline BET & $\begin{array}{l}\text { Surface area, pore structures, average } \\
\text { pore diameter, pore volume, and average } \\
\text { pores of BC }\end{array}$ & $\begin{array}{l}1057 \mathrm{~m}^{2} \mathrm{~g}^{-1} ; \text { macroporosity and microporosity; } 5.2 \mathrm{~nm} ; \\
0.24 \mathrm{mLg}^{-1} ; 3.3 \mathrm{~nm}\end{array}$ & {$[63,125]$} \\
\hline Boehm titration & Acidic and basic functional groups & $\begin{array}{l}\text { Functional groups determined include carboxylic, } \\
\text { lactonic, and phenolic }\end{array}$ & {$[45,65]$} \\
\hline FTIR/FTIS & $\begin{array}{l}\text { Changes that occur in BC preparations as } \\
\text { well as chemical functional groups } \\
\text { present on the original BC }\end{array}$ & $\begin{array}{l}\text { Changes include dehydration, pyrolysis, graphene } \\
\text { nucleation, and finally carbonization; O-H } \\
\left(3600-3100 \mathrm{~cm}^{-1}\right), \mathrm{C}=\mathrm{C} \text { and } \mathrm{C}=\mathrm{O} \text { stretching } \\
\left(1740-1600 \mathrm{~cm}^{-1}\right) \text {, } \\
\text { C-O-C symmetric stretching }\left(1097 \mathrm{~cm}^{-1}\right),- \text { COOMe } \\
\left(1400-1500 \mathrm{~cm}^{-1}\right) \text {, and so on }\end{array}$ & {$[66-68]$} \\
\hline CEC & $\begin{array}{l}\text { Measure of the surface charge in soil or } \\
\text { BC }\end{array}$ & $\begin{array}{l}\text { At aging } 278 \text { to } 518 \mathrm{mmol}_{\mathrm{c}} \mathrm{kg}^{-1}, \\
10.2 \text { to } 69.2 \mathrm{mmol}_{\mathrm{c}} \mathrm{kg}^{-1} \text {, at neutral } \mathrm{pH} \text { and } 16.2 \pm 6.0 \text { and } \\
21.0 \pm 17.2 \mathrm{mmol}_{\mathrm{c}} \mathrm{kg}^{-1} \text { for } \mathrm{BC} \text { produced at } 400 \text { and } 600^{\circ} \mathrm{C}\end{array}$ & {$[19,69]$} \\
\hline
\end{tabular}

TABLE 3: Organic contaminants adsorbed by BC produced from different biomass precursors.

\begin{tabular}{|c|c|c|}
\hline Source of BC & Organic pollutant sorbed & References \\
\hline Pine needle & $\begin{array}{l}\text { Naphthalene, nitrobenzene, } \\
\text { and m-dinitrobenzene from } \\
\text { waste water }\end{array}$ & {$[83]$} \\
\hline Bamboo & Pentachlorophenol & [29] \\
\hline $\begin{array}{l}\text { Bamboo, Brazilian } \\
\text { pepper wood, and } \\
\text { sugarcane bagasse }\end{array}$ & $\begin{array}{l}\text { Sulfamethoxazole from waste } \\
\text { water }\end{array}$ & {$[94]$} \\
\hline Wheat straw & Hexachlorobenzene & {$[25]$} \\
\hline $\begin{array}{l}\text { Hardwood, } \\
\text { softwood, and } \\
\text { grass }\end{array}$ & Catechol and humic acid & [19] \\
\hline
\end{tabular}

to the process. The residence time of the process is below $30 \mathrm{~min}$, and the pyrolytic temperature in the reactor is in the range of $330-650^{\circ} \mathrm{C}$ [40]. The process results mainly in gaseous and solid products such as BC. In addition to that, a limited number or no number of condensates are formed [44]. While oxygen supplied to the carbonization process is a feature of gasification technologies, both process temperature and the product spectrum (delivery between solid, liquid, and gaseous output) of flash carbonization are exceptional for gasification processes [45].

It can be observed that typical solid products yields obtained by gasification and fast pyrolysis process are significantly lower as compared to the solid product yields of slow pyrolysis, flash carbonization, hydrothermal carbonization, and torrefaction [39]. Recent studies by Dowie et al. revealed the experimental pyrolysis conditions performed at the heating rate of about $10 \mathrm{k} / \mathrm{min}$ up to the press cubed pyrolytic temperature ranging from 673 to $973 \mathrm{~K} \mathrm{[46].} \mathrm{The} \mathrm{yields} \mathrm{of}$ the resulting BC products are in the range of $25-40 \mathrm{wt} \%$. The yield was observed to decrease slightly at higher pyrolysis temperature, which should be attributed to the volatilization of other volatile products from the component of the biomass.
Pellera et al. [47] also deduced that the BC yields of rice husk and compost derived after hydrothermal pyrolysis were about $62.5 \%$, while olive pomace and organic waste were quite lower at $37.5 \%$. Concerning the BCs produced through pyrolysis, the increase of pyrolytic temperature leads to a decrease in the yield for all produced materials. Specifically, the yields at $300^{\circ} \mathrm{C}$ and $600^{\circ} \mathrm{C}$ were $32.8 \%$ and $31.9 \%$ for rice husks, 39.3 and $26.7 \%$ for olive pomace, $39.6 \%$ and $32.8 \%$ for orange waste, and $78.7 \%$ and $46 \%$ for compost, respectively. The development of integrated systems that produce BC at higher efficiency by slow pyrolysis is still, therefore, mainly on the research scale with technology commercially deployed only at a handful of research centres and locations.

\section{Quantification and Characterization of BC}

3.1. Quantification of BC. The major aim of quantification is to distinguish $\mathrm{BC}$ from soil organic matter and from other forms of black carbons produced from varieties of biomasses. Many of the potential techniques depend on spectroscopic characteristics rather than physical separation or isolation. Some of the techniques that most effectively distinguish different types of $\mathrm{BC}$ can also be used to characterize individual $\mathrm{BC}$ wastes (or collection of fragments) recovered from both soil and solution systems. An assessment of pure samples removes the matrix effects, but where function of a recalcitrant component depends on its surface characteristics or those of accessible pores, separation of active and inactive components presents a significant challenge [29].

Classifying $\mathrm{BC}$ is principally problematic on the basis of its chemical complexity and diversity, yet characteristically uncreative nature. Due to its recalcitrance nature, $\mathrm{BC}$ cannot eloquently be extracted from soil using chemical methods, though potential biomarkers may be. The results from studies using the physical location of BC within a soil matrix $[40,48]$ suggest that usefulness of physical separations using density or means other than hand sampling approach (which is restricted to very small samples) is susceptible to site factors. 
Until recently, the most practical methods have sought to remove nonblack components (i.e., oil organic matter and mineral carbonates) with subsequent evaluation of the residue. However, for quantifying $\mathrm{BC}$, particularly this type of quantification may be affected by the presence of the more frequent recalcitrant black carbon forms, as well as by the presence of highly resistant organic carbon compounds, such as those stabilized on the biomass not incompletely removed, which in some cases are estimated alone [4].

Different technical methods differentiate components of increasing minimum stability incompletely charred biomass, BC, charcoal, activated carbon, soot, and graphitic black carbon [49]. Leaching method in this grouping includes removal of nonblack carbon by chemical oxidation (e.g., sodium chlorite and potassium dichromate), using ultraviolet radiation, or by a thermal approach [50]. Hydrolysis pyrolysis ( $\mathrm{HyPy})$ is an alternative way to the removal of nonblack carbon [51], which evolved gas analysis from the character of the varied gaseous products of thermal decomposition. A combined chemothermal oxidation method, with a temperature of threshold [34], forms the foundation of a benchmark procedure for the determination of fixed carbon, which is composed of the most stable fraction of black carbon and has the more stable component of $\mathrm{BC}$.

Virtual separations have conventionally been based on spectroscopic techniques in combination with pretreatment (or other allowance) for numeral interference, for example, using hydrofluoric acid [52], pyrolysis gas chromatography mass spectroscopy (PyCG/MS), and solid state ${ }^{13} \mathrm{C}$ nuclear magnetic resonance $\left({ }^{13} \mathrm{CNMR}\right)$ spectroscopy with crosspolarization, block deterioration, and combined with magic angle spinning (MAS) [49] or chemically extracted and purified biomass products, particularly benzene polycarboxylic acid (BPCA) [53] and laevoglucose [54]. A further approach well thought of in this class is matrix-assisted laser desorption ionization (MALDI-TOF) [55].

The utilization of these methods depends on the purpose of the analysis and the specific nature of the target fraction, so even though all have been evaluated for a set of environmental and black carbon samples in a ring trial [56], there remains comparatively little agreement as to a widespread paradigm. Since most methods depend on progressive segregation which are based on increasing recalcitrant soil organic matter, graphitic and soot fraction, it is easy to know the content of relatively less condensed (stable) charcoal or BC fractions [57]. On the other hand, UV or chemical oxidation with elemental and ${ }^{13} \mathrm{CNMR}$ analysis of residues, thermal analysis $[50,56]$, and $\mathrm{PyHy}[51]$ were identified as the most promising techniques.

A partial new development in the quantification of $\mathrm{BC}$ has been the use of correlative techniques based on mid-infrared (MIR) spectroscopy. Initially evaluated for the estimation of organic carbon content of bulk soil and solution samples, among other key properties, algorithms have been utilized for relating MIR response spectrum to $\mathrm{BC}$, using a calibration set assessed using UV-oxidation method. The method has also been employed to evaluate charcoal content in region evaluation using archived soil [17] and holds potential for comparable assessments in the worldwide contexts.
3.2. Chemical Characterization. The original biomass feedstock and its $\mathrm{BC}$ can be subjected to a range of analyses in order to provide the basic physicochemical characteristics of each raw and pyrolyzed material. These physicochemical characterizations are displayed in Figure 2.

The chemical characteristics of individual feedstock species and therefore of $\mathrm{BC}$ derived from the feedstock have always been shown to vary significantly both spatially and temporarily [34]. BC production is often assessed through changes that might occur in the elemental concentrations of $\mathrm{C}, \mathrm{H}, \mathrm{O}, \mathrm{S}$, and $\mathrm{N}$ and associated ratios [49]. It is well known that fixed carbon is the solid combustible residue that remains after a particle sample is carbonized and volatile matter is expelled $[58,59]$. Thus, it is used as an estimate of the number of carbonaceous substances that will be yielded from a solid sample. Particularly, H/C and O/C ratios are used to determine the degree of aromaticity and maturation, as is often described in Van Krevelen diagrams [56]. Yu et al. on their recent work [60], where they used BC-based catalyst in the transesterification of canola oil, found out that the elemental analysis showed a decrease in the $\mathrm{H} / \mathrm{C}$ and $\mathrm{O} / \mathrm{C}$ ratios with increasing temperature of pyrolysis. Elemental ratios of $\mathrm{O} / \mathrm{C}, \mathrm{O} / \mathrm{H}$, and $\mathrm{C} / \mathrm{H}$ have been found to provide a reliable measure of both the extent of pyrolysis and level of oxidative adjustment of $\mathrm{BC}$ in the soil and solution systems and are relatively straightforward to be determined [60, 61].

BET (Brunauer, Emmett, and Teller) areas increased with an increase of carbon burn-off, irrespective of the pyrolytic temperature [56]. This indicates that the burn-off of the carbon has the most significant consequence on the increase of the surface area. In general, the surface area, pore volume, and average pore size increased with residence time and pyrolytic temperature [62]. Qiu et al. determined the BET surface area of BC $\left(1057 \mathrm{~m}^{2} \mathrm{~g}^{-1}\right)$ which was slightly higher than that of AC $\left(970 \mathrm{~m}^{2} \mathrm{~g}^{-1}\right)$. The micropore volume of BC $\left(0.24 \mathrm{~mL} \mathrm{~g}^{-1}\right)$ was again smaller than that of activated carbon $\left(0.32 \mathrm{~mL} \mathrm{~g}^{-1}\right)$, dependable with the average pore diameter of the former $(5.2 \mathrm{~nm})$ being larger than the latter $(3.3 \mathrm{~nm})$ [63]. Cheng et al. worked extensively on the magnetic BC for the sorption of organic pollutants and phosphates determined that the surface areas (internal and external surface areas) of BCs were fewer than other BCs, whereas the average pore radius use of the former was larger than the latter [64]. This might be due to the magnetic BCs containing substantial amount of the iron oxide, which have smaller surface areas and plentiful temporary pores. Table 2 shows few chemical characterizations of $\mathrm{BC}$ from the paper reviewed.

Operational determination of acidic and basic functional groups on $\mathrm{BC}$ can be performed by Boehm titration [65] in which the $\mathrm{BC}$ is equilibrated in the presence of consecutively strong bases $\left(\mathrm{HCO}_{3}{ }^{-}, \mathrm{CO}_{3}{ }^{2-}, \mathrm{OH}^{-}\right.$, and ethoxides) or strong acids $\left(\mathrm{H}_{2} \mathrm{SO}_{4}, \mathrm{HCl}\right.$, and $\left.\mathrm{HNO}_{3}\right)$ followed by titration of the extract with strong acid or base to estimate the fraction that reacted. Differences in the number of the acids or bases needed are used to estimate their relative amounts of carboxylic, lactonic, phenolic, and carboxylic functional groups (base equilibration) or basic functionalities (acidic equilibration) [45]. Characterization of $\mathrm{BC}$ used as soil 
amendment and, the ethoxides equilibration is commonly omitted as it measures functional groups that are dissociated only at a very high $\mathrm{pH}$, while immobilization of pollutants occurs at moderately low $\mathrm{pH}$ [64]. The Boehm titration operates well for hydrophobic BC but a major shortfall appears when a significant number of biooils or mineral surfaces are present [47].

In carbonization of biomass feedstock for the preparation of $\mathrm{BC}$ four regions of changes are normally observed at nonhydrothermal conditions [31]. They include dehydration, pyrolysis, graphene nucleation, and finally carbonization. These changes can be observed when $\mathrm{BC}$ is subjected to Fourier transform infrared spectroscopy (FTIS/FTIR). Again FTIS/FTIR can also be used to identify the chemical functional groups present on the original BC [66]. As enumerated by Lee et al., their recent work [67] showed that samples used in preparing gasification $\mathrm{BC}\left(700^{\circ} \mathrm{C}\right)$ and fast pyrolysis BC $\left(450^{\circ} \mathrm{C}\right)$ showed characteristics bonds similar to those of cellulose. It is clear between the baseline corrected FTIR spectra of the sample that with increase in temperature, there is a remarkable decrease in features associated with $\mathrm{O}-\mathrm{H}\left(3600-3100 \mathrm{~cm}^{-1}\right), \mathrm{C}=\mathrm{C}$ and $\mathrm{C}=\mathrm{O}$ stretching (1740$1600 \mathrm{~cm}^{-1}$ ) and aromatic $\mathrm{C}=\mathrm{C}$ and $\mathrm{C}-\mathrm{H}$ deformation modes of alkenes $\left(1500-1100 \mathrm{~cm}^{-1}\right)$, and the $\mathrm{C}-\mathrm{O}-\mathrm{C}$ symmetric stretching $\left(1097 \mathrm{~cm}^{-1}\right)$ characteristics of cellulose and hemicelluloses. In the combined sorption of $\mathrm{Pb}^{2+}$ and its mechanism case study by Qiu et al. [66], BC was found to contain an abundant amount of carboxyl and hydroxyl groups through FTIR spectra analysis of their sludge-derived BC (SDBC). Again, the band for the complexed carboxyl (-COOMe) shows no clear change effect after being replaced by lead at the range of $1400-1500 \mathrm{~cm}^{-1}$, possibly due to the corresponding substitution of the cations. The remarkable shift of the band at $3404-3406 \mathrm{~cm}^{-1}(\mathrm{pH}=2.0), 3420 \mathrm{~cm}^{-1}(\mathrm{pH}=3.0)$, $3429 \mathrm{~cm}^{-1}(\mathrm{pH}=4)$, and $3422 \mathrm{~cm}^{-1}(\mathrm{pH}=5.0)$ supported the proposed complexation between $\mathrm{Pb}^{2+}$ and hydroxyl as well as carboxyl functional groups [68]. Additionally, the band at $1032 \mathrm{~cm}^{-1}$ was shifted to $1034 \mathrm{~cm}^{-1}(\mathrm{pH}=4.0)$ and $1035 \mathrm{~cm}^{-1}$ $(\mathrm{pH}=5.0)$; they again concluded that it is an indication of coordination of $\mathrm{Pb}^{2+}$ with carboxylate groups.

Cationic exchange capacity (CEC) as widely known in agronomical sector is the measure of the surface charge in soil or BC, which increases as the BC ages [34] and has been ascribed to an increase in some oxygenated functional groups on the surface of the $\mathrm{BC}$ [64]. The most distinct change in any absolute CEC values was observed for the $\mathrm{BC}$ as a result of time where it increased from 278 to $518 \mathrm{mmol}_{\mathrm{c}} \mathrm{kg}^{-1}$, most likely because oxidation process created hydroxyl and carboxylic acid functional groups [69].

Biomass feedstock is a major factor governing the status of such physicochemical properties; pyrolytic temperature is the most significant process parameter; carbon content of $\mathrm{BC}$ is nondirectly related to $\mathrm{BC}$ yield, increasing from 53 to $83 \%$ and from 300 to $800^{\circ} \mathrm{C}$ in one study, while yield of $\mathrm{BC}$ decreased from 67 to $26 \%$ [19].

3.3. Physical Characterization. Scanning electron microscopy (SEM) is a microscopic technique in determining the image macroporosity and physical morphology of solid substances [17]. The macroporous structure (pores of approximately $1 \mu \mathrm{m}$ diameter) of BC produced from cellulose plant material depends upon the intrinsic architecture of the feedstock, and it is potentially important to water-holding and adsorptive capacity of pollutant in soil and solution systems $[17,70]$. SEM micrographs of BCCS (cotton (Gossypium herbaceum) straw) and BCPS (potato (Solanum tuberosum) straw) obtained in our previous study are shown in Figure 3 [71]. The BCs produced at different pyrolytic temperature had a distinguishable honey-comb-like structure due to the presence of tubular structures originally emanating from plant cells. As a result of these well-developed pores, the $\mathrm{BCs}$ possessed a high BET surface area. The significance of pyrolytic temperature leads to the suggestion that $\mathrm{BC}$ produced at low pyrolytic temperature may be appropriate for regulating release of fertilizer nutrients [72], while high temperatures would lead to a material analogous to $\mathrm{AC}$ in environmental remediation [70]. It can also be detected that the surfaces of low temperatures $\mathrm{BC}$ can be hydrophobic, and this may reduce its capacity to store water in soil as well as adsorb pollutants. The form, type, preliminary preparation steps and size of the biomass feedstock, and type of pyrolysis product may affect the characteristics, nature, quality, and potential use of BC [73]. Initially, the ratio of exposed to total surface area of BC will be affected by its size. Additionally, although low pyrolytic temperature $\mathrm{BC}$ is stronger than high temperature products, it is brittle and pores are abraded into fine fractions once incorporated into the soil.

In explaining the relationship between the mechanism of heavy metal sorption and SEM, Qiu et al. proposed a vivid explanation [66]. They observed bright zones on the pores surface of $\mathrm{Pb}$-loaded $\mathrm{BC}$ at $\mathrm{pH}=5$ in the SEM photography. Its EDX spectrum represents the red surface and additionally established the occurrence of silicon and phosphorus, which might exist in the form of $5 \mathrm{PbO} \cdot \mathrm{P}_{2} \mathrm{O}_{5} \cdot \mathrm{SiO}_{2}$ (lead phosphate silicate) precipitates which was again identified by XRD spectra. They concluded that the precipitates should be an important means of modelling the mechanism for $\mathrm{Pb}^{2+}$ removal from soil system and again can be related to solution system.

\section{Sorptive Properties of BC}

Unlike any other carbonaceous fuel, BC is generally used as a soil amendment and in water treatment. The physicochemical properties of BC such as surface area, charged surface, and functional group vary appreciably based on the biomass source and pyrolysis condition, which affect the adsorptive capacity of BC to heavy metals and organic compounds.

4.1. Sorption of Heavy Metals. In cases of BC nature, the most appropriate and effective method for heavy metal or trace metals removal has been proven to be adsorption using BC $[26,30,74-76]$. The adsorption mechanisms mainly include electrostatic interaction, ionic exchange, chemical precipitation, and complexion with functional groups on BC surface $[26,34,74,76]$. Mechanisms of heavy metal sorption 
by BC can be systematically investigated using different methods, including adsorption isotherms and kinetic models, desorption studies, and industrial analysis including XRD, FTIR, and SEM. Sorption may encompass the electrostatic attraction and innersphere complex with free and complexed carboxyl, alcoholic hydroxyl, or phenolic hydroxyl groups on BC surface (such as $\mathrm{R}-\mathrm{COOH},-\mathrm{COOMe},-\mathrm{ROH}$, and -ROMe, where $\mathrm{Me}$ represents the central metal atoms) as well as coprecipitation or superficial precipitation [66]. Carboxyl (R-COOH) and alcoholic or phenolic hydroxyl groups $(\mathrm{R}-\mathrm{OH})$ are usually acknowledged as the main groups contributing to coordination between heavy metals and sorbent surface [77]. Comparing with organic pollutants, inadequate information is available on the factors regulating the immobilization of inorganic contaminants on $\mathrm{BC}$ and the impact of $\mathrm{BC}$ on heavy metal retention in soils [78]. Studies utilizing ACs have suggested that, depending on the solution composition and the carbon type, the following mechanism predominates: (1) electrostatic interaction between metal cations and negatively charged carbon surfaces (above $\mathrm{pH}_{\mathrm{pze}}$ of carbon) and (2) ionic exchange between ionisable protons at the surface of the acidic carbonaceous adsorbent via proton exchange $\left(-\mathrm{C} \pi-\mathrm{H}_{3} \mathrm{O}^{+}\right)[47,79]$ or coordination of d-electrons [22]. Mineral impurities such as ash and basic nitrogen groups (e.g., pyridine) can serve as additional adsorption sites of the carbonaceous material. Interpretation of the thermodynamic parameters of metal sorption to BCs and activated carbons reveals that sorption is an endothermic physical process $[26,80,81]$. That is, an electrostatic interaction occurs between the positively charged metal cations and $\pi$-electrons associated with either $\mathrm{C}=\mathrm{O}$ ligands or (more likely) $\mathrm{C}=\mathrm{C}$ of a shared electron cloud on aromatic structures in $\mathrm{BC}[68,74,81,82]$. The authors suggested that $\mathrm{BC}$ reduces $\mathrm{Pb}$ mobility due to the precipitation of insoluble $\mathrm{Pb}$-phosphates. BCs derived from manure have been reported to be rich in $\mathrm{P}$ [22]. Solution $\mathrm{pH}$ is an important parameter that affects both the surface charge density of the adsorbent and the metal ion speciation [83]. Chen et al. also observed that $\mathrm{pH}$ significantly affected the adsorption of $\mathrm{Cu}$ (II) and $\mathrm{Zn}$ (II) adsorption onto $\mathrm{BC}$ and was more pronounced for $\mathrm{CS} 600^{\circ} \mathrm{C}$ (corn straw based $\mathrm{BC}$ produced at $600^{\circ} \mathrm{C}$ ) and $\mathrm{HW} 450^{\circ} \mathrm{C}$ (hardwood based $\mathrm{BC}$ produced at $450^{\circ} \mathrm{C}$ ) [84]. They found out that the adsorption capacities $q_{e}\left(\mathrm{mg} \mathrm{g}^{-1}\right)$ of these BCs increased with increasing of $\mathrm{pH}$ values of the test solution until it attains its maximum at $\mathrm{pH}$ 5. Measurement of the change in solution $\mathrm{pH}$ after $\mathrm{BC}$ addition and adsorption equilibrium showed that both BCs had a buffering capacity that was distinguished from that of the electrolyte.

4.2. Sorption of Organic Pollutants. The adsorptive capacity of BC for organic contaminants depends upon the type of biomass and pyrolysis conditions. It has been found that $\mathrm{BC}$ has large adsorptive capacity for pesticide, persistent organic pollutant (PAHs, PCBs, etc.), chlorinated compounds, and dyes [63, 85-92]. Table 3 shows BC produced from different biomasses used in the adsorption of some organic pollutants. The sorption of organic contaminants of both wood and manure based BC was found to be assisted by $\pi$-electrons interactions [83] and progressed with a pore-filling mechanism process [93]. Previous work has been done on plantresidue derived $\mathrm{BC}$ for sorbing organic contaminants. Chen et al. reported that pine-needle derived $\mathrm{BC}$ was effective in removing naphthalene, nitrobenzene, and m-dinitrobenzene from water [83]. Lou et al. showed that agricultural soil amended with bamboo derived BC improved the leachability and bioavailability of pentachlorophenol [29]. Yao et al. again reported that $\mathrm{BCs}$ derived from bamboo, Brazilian pepper wood, sugarcane bagasse, and hickory wood were successful in removing sulfamethoxazole from water [94] and De Wild et al. finally assessed the bioavailability assessment of hexachlorobenzene in soil by employing wheat straw based BC [25].

Addition of $\mathrm{BC}$ has been shown to increase sorption and to decrease the dissipation of pesticides in soils [95]. Finally, previous studies have demonstrated that carbonaceous materials, such as peat $[24,96]$, soya bean stalk [96], and coke [97] based BC, can effectively regulate organic contaminants and decrease the bioavailability of organic contaminants by repartitioning organic contaminants to carbonaceous adsorbents. However, it is still inexact if $\mathrm{BC}$ is suitable for the sequestration of organic pollutants. Furthermore, most researches on the likelihood of regulating organic pollution with carbonaceous materials have been performed by equilibrium adsorption experiments [29]. Yet, soil column leaching experiments were found to be more idyllic to simulate the actual situation of in situ soil organic pollution control and to understand the possibility of using carbonaceous materials to guard plant and groundwater [98].

In the collective sorption of pentachlorophenol (PCP) case study [99], the BC produced from rice straw (RC) and fly ash (FC) was found to have exhibited encouraging sorption ability. It was again found out that the sorption capacity of the BC supplemented sediments increased with an increase in BC content in the sediments. The parameters were well fitted by the Freundlich and dual mode models.

The sorption of both organic and heavy metal pollutants may be influenced by several factors, such as $\mathrm{pH}$ [100], specific surface area [101], particle size, time of exposure of pollutants, and soil moisture [99]. Some researches have indicated that the adsorptive competition occurs when multicontaminants are adsorbed onto BC. Inyang et al. prepared two BCs from anaerobically digested biomass. The adsorptions of $\mathrm{Cu}^{2+}, \mathrm{Cd}^{2+}, \mathrm{Pb}^{2+}$, and $\mathrm{Ni}^{2+}$ onto $\mathrm{BCs}$ were investigated [102]. It was found that the BCs demonstrated a better ability to remove $\mathrm{Ni}^{2+}$ and $\mathrm{Cd}^{2+}$. The competitive adsorption between $\mathrm{Cu}(\mathrm{II})$ and $\mathrm{Zn}$ (II) onto $\mathrm{BCs}$ produced from pyrolysis of hardwood and corn straw occurred when the ion concentrations were kept at $1.0 \mathrm{mM} / \mathrm{L}$ [84]. The results reported by Uchimiya indicated that the adsorption of deisopropylatrazine onto broiler litter BC was inhibited in the presence of $\mathrm{Cu}$ (II) in binary-solute experiments [82].

\section{Effect of BC on Bioavailability of Heavy Metals and Organic Pollutants in Soil}

Soil is well known for its adsorption and CEC properties. The adsorption of heavy metals by soils and $\mathrm{BC}$ effect on the 
mobility and fate of the heavy metals have been extensively studied in recent times [57, 91, 103-108]. The results showed that the addition of wood BC to soil did not have any significant effect on the dry matter yield of maize plants, even at the highest rate of application, but BC application decreased the concentration of $\mathrm{As}, \mathrm{Cd}$, and $\mathrm{Cu}$ in maize shoots, which depended upon amount of $\mathrm{BC}$ addition, $\mathrm{pH}$ values of soils, and ability of metal to adsorb on BC [105]. When BCs made from sludge and lignite were applied to soil, not only are the properties of the soil improved but also the mobility of the HMs in the mixtures, which is connected with the characteristics of the matrix, may be affected [82]. In their recent work [20], Beesley and Marmiroli found that there was an important negative relationship between $\mathrm{pH}$ and cadmium in eluates from soil when it had passed through BC, showing that raising the $\mathrm{pH}$ could be the mechanisms by which $\mathrm{Cd}$ movement was reduced by $\mathrm{BC}$, considering the high soluble $\mathrm{Cd}$ concentration in the soil. Other notable researches have also indicated that increase in soil $\mathrm{pH}$ will subsequently lead to an increase of $\mathrm{Cd}$ in solution by adsorption [109].

The sorption of anthropogenic hydrophobic organic compounds (HOCs) (e.g., PAHs, polychlorinated biphenyls, PCBs, pesticides, and herbicides) in soil and sediments is generally described based on two coexisting and simultaneous processes, absorbing into natural (amorphous) organic matter (NOM) and adsorption into naturally occurring $\mathrm{BC}$ material [110]. Comparatively, to that of NOM, BC (including soot) generally holds up to 10-1000 times higher sorption affinity toward such compounds [111]. It has been estimated that $\mathrm{BC}$ can account for as much as $80-90 \%$ of total uptake of trace HOC in soils and sediments [110]. BC application is therefore expected and accepted to improve the overall sorption capacity of soil [112] and, consequently, influence toxicity, transport, and fate of trace contaminants, which may be already or are to be added to soils. Despite the fact that little is still known on the microscale process controlling sorption to BC [113] in soils and sediments, it has been suggested that it is mechanistically different from the conventional sorption model for NOM and that it is also a less reversible process. While adsorption onto $\mathrm{BC}$ has little or no concentration dependence, adsorption to $\mathrm{BC}$ has been shown to be strongly concentration dependent [114], with affinity decreasing for increasing solute concentration.

$\mathrm{BC}$ is applied to soil for the conditioning and fertilization purposes; application can also be favourable in reduction of toxic components. Recent studies have shown that $\mathrm{BC}$ is also capable of adsorbing heavy metals such as lead, cadmium, nickel, and some notable organic contaminants that contaminated soils which can cause harm to human, plants, and animals [115]. For that reason, BC as an additive to a soil can be expected to improve its overall adsorption capacity impacting toxicity because there is a decrease in transportability and depletion of the presence of metal or organic compounds. Due to its low cost and limited environmental impact, BC would be a promising strategy for remediation of polluted environment [116]. Recent studies have shown that $\mathrm{BC}$ in collaboration with activation have comparable adsorption and absorption abilities, which plays a great role in removal of contaminants such as lead $(\mathrm{Pb})$ [115].
Considering recent experimental methods, results have shown that metal ions are strongly adsorbed onto specific active sites containing phenolic and carboxyl functionalities of the surface of BC [117]. Reviewing of BC application to wastewater treatment, contaminants such as heavy metal (lead) intake by BC, involves replacing already existing ions that might be present on the $\mathrm{BC}$ with the metal ion in solution system, suggesting a potential correlation between content of the $\mathrm{BC}$ and its remediation potential for metals [84]. With my research, monitoring, reviewing, and basic understanding of $\mathrm{BC}$, proper or accurate application to benefit environment concerns will be in the near future the simplicity of production methods to the capability for integration into less developed countries.

Although amending soils with $\mathrm{BCs}$ will reduce the bioavailability and hence the toxicity of contaminants, it is also likely for them to reduce the rate at which organic compounds are degraded in the environment precisely due to this reduction in bioavailability [118]. A number of studies have shown that the presence of $\mathrm{BC}$ or black carbons can reduce the degradation of organic pesticides $[104,119]$ and other organic contaminants $[103,120,121]$. This should be considered when amending soils with BC, especially when soils contain organic compounds that would otherwise degrade relatively rapidly. Also, this decreased bioavailability can be detrimental in terms of reducing herbicide efficiency, resulting in the need for higher application rates of these chemicals [122]. In some occasions, BCs have been found to have a negative effect on some sediment and soil organisms, especially those that live in intimate contact and ingest large volumes of sediment and soil $[123,124]$.

\section{Conclusions}

$\mathrm{BC}$ can be derived from a wide range of sewage sludge, forest residue, organic and agricultural wastes biomass feedstocks, at different pyrolysis conditions and at a range of balances. The characteristics of BCs identified by physical and chemical methods reveal the basic structure and property of BC. Due to its large surface area, charged surface, and functional groups, BC is of great potential to adsorb heavy metal and organic contaminants. Addition of BC should decrease the bioavailability, toxicity, and mobility of organic and inorganic pollutants. This has the potential to be beneficial for immobilization of contaminants with high concentrations. However, the amending of $\mathrm{BC}$ also has negative effect on the efficacy of pesticides and herbicides, the degradation rate of organics and some sediment, and soil organisms.

\section{Conflict of Interests}

The authors declare that there is no conflict of interests regarding the publication of this paper.

\section{Acknowledgments}

This paper was financially supported by the National Natural Science Foundation of China (21167007, 21467013), the Specialized Research Fund for the Doctoral Program of Higher 
Education of China (20136204110003), and the Youth Science Foundation of Lanzhou Jiaotong University (2013015).

\section{References}

[1] S. J. Lehmann, Biochar for Environmental Management, Earthscan, Oxford, UK, 2009.

[2] S. Kajitani, L. H. Tay, S. Zhang, and Z. C. Li, "Mechanisms and kinetic modelling of steam gasification of brown coal in the presence of volatile-char interactions," Fuel, vol. 103, pp. 7-13, 2013.

[3] H. Aydın, Y. Buluta, and C. Yerlikayab, "Removal of copper (II) from aqueous solution by adsorption onto low-cost adsorbents," Journal of Environmental Management, vol. 87, pp. 37-45, 2008.

[4] M. Amutio, G. Lopez, J. Alvarez et al., "Flash pyrolysis of forestry residues from the Portuguese Central Inland Region within the framework of the BioREFINA-Ter project," Bioresource Technology, vol. 129, pp. 512-518, 2013.

[5] M. A. Rondon, J. Lehmann, J. Ramirez, and M. Hurtudo, "Biological nitrogen fixation by common beans (Phaseolus vulgaris L.) increases with bio-char additions," Biology and Fertility of Soils, vol. 43, no. 6, pp. 699-708, 2007.

[6] J. E. Thies, M. C. Rilling, J. Lehmann, and S. Joseph, "Characteristics of biochar: biological properties," in BC for Environmental Management, Earthscan, New York, NY, USA, 2009.

[7] D. A. Wardle, M. Nilsson, and O. Zackrisson, "Fire-derived charcoal causes loss of forest humus," Science, vol. 320, no. 5876, p. 629, 2008.

[8] E. Marris, "Putting the carbon back: black is the new green," Nature, vol. 442, no. 7103, pp. 624-626, 2006.

[9] J. Lehmann, “A handful of carbon," Nature, vol. 447, no. 7141, pp. 143-144, 2007.

[10] R. Renner, "Rethinking biochar," Environmental Science and Technology, vol. 41, no. 17, pp. 5932-5933, 2007.

[11] B. Fraser, "High-tech charcoal fights climate change," Environmental Science \& Technology, vol. 44, no. 2, pp. 548-549, 2010.

[12] C. J. Atkinson, J. D. Fitzgerald, and N. A. Hipps, "Potential mechanisms for achieving agricultural benefits from biochar application to temperate soils: a review," Plant and Soil, vol. 337, no. 1, pp. 1-18, 2010.

[13] E. R. Graber, Y. M. Harel, M. Kolton et al., "Biochar impact on development and productivity of pepper and tomato grown in fertigated soilless media," Plant and Soil, vol. 337, no. 1, pp. 481496, 2010.

[14] C. L. M. Khodadad, A. R. Zimmerman, S. J. Green, S. Uthandi, and J. S. Foster, "Taxa-specific changes in soil microbial community composition induced by pyrogenic carbon amendments," Soil Biology and Biochemistry, vol. 43, no. 2, pp. 385-392, 2011.

[15] D. D. Warnock, J. Lehmann, T. W. Kuper, and M. C. Rillig, "Mycorrhizal responses to biochar in soil-concepts and mechanisms," Plant and Soil, vol. 300, no. 1-2, pp. 9-20, 2007.

[16] Y. Chen, Y. Shinogi, and M. Taira, "Influence of biochar use on sugarcane growth, soil parameters, and groundwater quality," Australian Journal of Soil Research, vol. 48, no. 6-7, pp. 526-530, 2010.

[17] D. Angin, "Effect of pyrolysis temperature and heating rate on biochar obtained from pyrolysis of safflower seed press cake," Bioresource Technology, vol. 128, pp. 593-597, 2013.

[18] P. Shivaram, Y. K. Leong, H. Yang, and D. K. Zhang, "Flow and yield stress behaviour of ultrafine Mallee biochar slurry fuels: the effect of particle size distribution and additives," Fuel, vol. 104, pp. 326-332, 2013.

[19] R. A. Zimmerman, N. G. Kasozi, P. Nkedi-Kizza, and B. Gao, "Catechol and humic acid sorption onto a range of laboratoryproduced black carbons (biochars)," Environmental Science and Technology, vol. 44, pp. 6189-6195, 2010.

[20] L. Beeseley and M. Marmiroli, "The immobilisation and retention of soluble arsenic, cadmium and zinc by biochar," Environmental Pollution, vol. 159, no. 2, pp. 474-480, 2011.

[21] T. Xu, L. Lou, L. Luo, R. Cao, D. Duan, and Y. Chen, "Effect of bamboo biochar on pentachlorophenol leachability and bioavailability in agricultural soil," Science of the Total Environment, vol. 414, pp. 727-731, 2012.

[22] X. Cao and W. Harris, "Properties of dairy-manure-derived biochar pertinent to its potential use in remediation," Bioresource Technology, vol. 101, no. 14, pp. 5222-5228, 2010.

[23] W. Song and M. Guo, "Quality variations of poultry litter biochar generated at different pyrolysis temperatures," Journal of Analytical and Applied Pyrolysis, vol. 94, pp. 138-145, 2012.

[24] W. Tsai, S. Liu, and C. Hsieh, "Preparation and fuel properties of biochars from the pyrolysis of exhausted coffee residue," Journal of Analytical and Applied Pyrolysis, vol. 93, pp. 63-67, 2012.

[25] P. J. de Wild, W. J. J. Huijgen, and H. J. Heeres, "Pyrolysis of wheat straw-derived organosolv lignin," Journal of Analytical and Applied Pyrolysis, vol. 93, pp. 95-103, 2012.

[26] Z. Liu and F. Zhang, "Removal of lead from water using biochars prepared from hydrothermal liquefaction of biomass," Journal of Hazardous Materials, vol. 167, no. 1-3, pp. 933-939, 2009.

[27] X. Zhao, W. Ouyang, F. Hao et al., "Properties comparison of biochars from corn straw with different pretreatment and sorption behaviour of atrazine," Bioresource Technology, vol. 147, pp. 338-344, 2013.

[28] T. Wang, J. Cheng, J. Liu, C. Zhang, and X. Yu, "Effect of biochar amendment on the bioavailability of pesticide chlorantraniliprole in soil to earthworm," Ecotoxicology and Environmental Safety, vol. 83, pp. 96-101, 2012.

[29] L. Lou, L. Luo, Q. Yang et al., "Release of pentachlorophenol from black carbon-inclusive sediments under different environmental conditions," Chemosphere, vol. 88, no. 5, pp. 598-604, 2012.

[30] H. Lu, W. Zhang, Y. Yang, X. Huang, S. Wang, and R. Qiu, "Relative distribution of $\mathrm{Pb}^{2+}$ sorption mechanisms by sludgederived biochar," Water Research, vol. 46, no. 3, pp. 854-862, 2012.

[31] S. Zhou, D. Mourant, C. Lievens, Y. Wang, C. Li, and M. GarciaPerez, "Effect of sulfuric acid concentration on the yield and properties of the bio-oils obtained from the auger and fast pyrolysis of Douglas Fir," Fuel, vol. 104, pp. 536-546, 2013.

[32] L. Yang, M. Jin, C. Tong, and S. Xie, "Study of dynamic sorption and desorption of polycyclic aromatic hydrocarbons in siltyclay soil," Journal of Hazardous Materials, vol. 244-245, pp. 7785, 2013.

[33] M. De, R. Azargohar, A. K. Dalai, and S. R. Shewchuk, "Mercury removal by bio-char based modified activated carbons," Fuel, vol. 103, pp. 570-578, 2013.

[34] M. Zhang, B. Gao, S. Varnoosfaderani, A. Hebard, Y. Yao, and M. Inyang, "Preparation and characterization of a novel magnetic biochar for arsenic removal," Bioresource Technology, vol. 130, pp. 457-462, 2013.

[35] Y. Luo, M. Durenkamp, M. De Nobili, Q. Lin, B. J. Devonshire, and P. C. Brookes, "Microbial biomass growth, following incorporation of biochars produced at $350^{\circ} \mathrm{C}$ or $700^{\circ} \mathrm{C}$, in a silty-clay 
loam soil of high and low pH,' Soil Biology and Biochemistry, vol. 57, pp. 513-523, 2013.

[36] V. Asensio, F. A. Vega, M. L. Andrade, and E. F. Covelo, "Tree vegetation and waste amendments to improve the physical condition of copper mine soils," Chemosphere, vol. 90, no. 2, pp. 603-610, 2013.

[37] M. C. Rillig, M. Wagner, M. Salem et al., "Material derived from hydrothermal carbonization: effects on plant growth and arbuscular mycorrhiza," Applied Soil Ecology, vol. 45, no. 3, pp. 238-242, 2010.

[38] IEA Bioenergy, IEA Bioenergy Task 34: Pyrolysis, 2010, http://www.pyne.co.uk/?_id=76.

[39] S. Meyer, B. Glaser, and P. Quicker, “Technical, economical, and climate-related aspects of biochar production technologies: a literature review," Environmental Science and Technology, vol. 45, no. 22, pp. 9473-9483, 2011.

[40] D. P. Oliver, Y. F. Pan, J. S. Anderson et al., "Sorption of pesticides by a mineral sand mining by-product, neutralised used acid (NUA)," Science of the Total Environment, vol. 442, pp. 255-262, 2013.

[41] A. V. Bridgwater, "The production of biofuels and renewable chemicals by fast pyrolysis of biomass," International Journal of Global Energy Issues, vol. 27, no. 2, pp. 160-203, 2007.

[42] A. Funke and F. Ziegler, "Hydrothermal carbonization of biomass: a summary and discussion of chemical mechanisms for process engineering," Biofuels, Bioproducts and Biorefining, vol. 4, no. 2, pp. 160-177, 2010.

[43] J. A. Libra, K. S. Ro, C. Kammann et al., "Hydrothermal carbonization of biomass residuals: a comparative review of the chemistry, processes and applications of wet and dry pyrolysis," Biofuels, vol. 2, no. 1, pp. 71-106, 2011.

[44] S. Cheah, K. R. Gaston, Y. O. Parent et al., "Nickel cerium olivine catalyst for catalytic gasification of biomass," Applied Catalysis B: Environmental, vol. 134-135, pp. 34-45, 2013.

[45] I. Cohen-Ofri, R. Popovitz-Biro, and S. Weiner, "Structural characterization of modern and fossilized charcoal produced in natural fires as determined by using electron energy loss spectroscopy," Chemistry -A European Journal, vol. 13, no. 8, pp. 2306-2310, 2007.

[46] A. Dowie, A. Crosky, and P. Muroe, "Physical properties of biochar," in BC for Environmental Management, J. Lehmann and S. Joseph, Eds., pp. 47-82, Earthscan, London, UK, 2009.

[47] F. Pellera, A. Giannis, D. Kalderis et al., "Adsorption of $\mathrm{Cu}$ (II) ions from aqueous solutions on biochars prepared from agricultural by-products," Journal of Environmental Management, vol. 96, no. 1, pp. 35-42, 2012.

[48] R. Kröger, E. J. Dunne, J. Novak et al., "Downstream approaches to phosphorus management in agricultural landscapes: regional applicability and use," Science of the Total Environment, vol. 442, pp. 263-274, 2013.

[49] R. J. Smernik, J. A. Baldock, J. M. Oades, and A. K. Whittaker, "Determination of $\mathrm{T} 1 \rho \mathrm{H}$ relaxation rates in charred and uncharred wood and consequences for NMR quantitation," Solid State Nuclear Magnetic Resonance, vol. 22, no. 1, pp. 5070, 2002.

[50] J. M. De la Rosa, H. Knicke, E. Lopez-Capel, D. A. C. Manning, J. A. Gonzalez-Perez, and F. J. Gonzalez-Villa, "Direct detection of black carbon in soils by Py-GC/MS, carbon- $-{ }^{13} \mathrm{NMR}$ spectroscopy and thermogravimetric techniques," Soil Science Society of America Journal, vol. 72, no. 1, pp. 258-267, 2008.
[51] P. L. Ascough, M. I. Bird, F. Brock et al., "Hydropyrolysis as a new tool for radiocarbon pre-treatment and the quantification of black carbon," Quaternary Geochronology, vol. 4, no. 2, pp. 140-147, 2009.

[52] M. J. Simpson and P. G. Hatcher, "Determination of black carbon in natural organic matter by chemical oxidation and solidstate ${ }^{13} \mathrm{C}$ nuclear magnetic resonance spectroscopy," Organic Geochemistry, vol. 35, no. 8, pp. 923-935, 2004.

[53] S. Brodowski, W. Amelung, L. Haumaier, and W. Zech, "Black carbon contribution to stable humus in German arable soils," Geoderma, vol. 139, no. 1-2, pp. 220-228, 2007.

[54] L. J. Kuo, B. E. Herbert, and P. Louchouarn, "Can levoglucosan be used to characterize and quantify char/charcoal black carbon in environmental media?" Organic Geochemistry, vol. 39, no. 10, pp. 1466-1478, 2008.

[55] J. Bourke, M. Manley-Harris, C. Fushimi, K. Dowaki, T. Nunoura, and M. J. Antal Jr., "Do all carbonized charcoals have the same chemical structure? 2. A model of the chemical structure of carbonized charcoal," Industrial and Engineering Chemistry Research, vol. 46, no. 18, pp. 5954-5967, 2007.

[56] K. Hammes, R. J. Smernik, J. O. Skjemstad, and M. W. I. Schmidt, "Characterisation and evaluation of reference materials for black carbon analysis using elemental composition, colour, BET surface area and ${ }^{13} \mathrm{C}$ NMR spectroscopy," Applied Geochemistry, vol. 23, no. 8, pp. 2113-2122, 2008.

[57] X. L. Dong, L. Q. Ma, and Y. C. Li, "Characteristics and mechanisms of hexavalent chromium removal by biochar from sugar beet tailing," Journal of Hazardous Materials, vol. 190, no. 1-3, pp. 909-915, 2011.

[58] E. W. Murage, P. Voroney, and R. P. Beyaert, "Turnover of carbon in the free light fraction with and without charcoal as determined using the ${ }^{13} \mathrm{C}$ natural abundance method," Geoderma, vol. 138, no. 1-2, pp. 133-143, 2007.

[59] S. M. Haefele, Y. Konboon, W. Wongboon et al., "Effects and fate of biochar from rice residues in rice-based systems," Field Crops Research, vol. 121, no. 3, pp. 430-440, 2011.

[60] J. T. Yu, A. M. Dehkhoda, and N. Ellis, "Development of biochar-based catalyst for transesterification of canola oil," Energy and Fuels, vol. 25, no. 1, pp. 337-344, 2011.

[61] J. Lehmann, J. Gaunt, and M. Rondon, "Bio-char sequestration in terrestrial ecosystems-a review," Mitigation and Adaptation Strategies for Global Change, vol. 11, no. 2, pp. 403-427, 2006.

[62] M. S. H. K. Tushar, N. Mahinpey, A. Khan, H. Ibrahim, P. Kumar, and R. Idem, "Production, characterization and reactivity studies of chars produced by the isothermal pyrolysis of flax straw," Biomass and Bioenergy, vol. 37, pp. 97-105, 2012.

[63] Y. Qiu, Z. Zheng, Z. Zhou, and G. D. Sheng, "Effectiveness and mechanisms of dye adsorption on a straw-based biochar," Bioresource Technology, vol. 100, no. 21, pp. 5348-5351, 2009.

[64] S. Cheng, J. H. Jang, B. A. Dempsey, and B. E. Logam, "Efficient recovery of nano-sized iron oxide particles from synthetic acidmine drainage (AMD) water using fuel cell technologies," Water Research, vol. 45, no. 1, pp. 303-307, 2011.

[65] H. P. Boehm, "Some aspects of the surface chemistry of carbon blacks and other carbons," Carbon, vol. 32, no. 5, pp. 759-769, 1994.

[66] R. Qiu, H. Lu, W. Zhang, Y. Yang, X. Huang, and S. Wang, "Relative distribution of $\mathrm{Pb}^{2+}$ sorption mechanisms by sludgederived biochar," Water Research, vol. 46, no. 3, pp. 854-862, 2012. 
[67] J. W. Lee, M. Kidder, B. R. Evans et al., "Characterization of biochars produced from cornstovers for soil amendment," Environmental Science and Technology, vol. 44, no. 20, pp. 79707974, 2010.

[68] A. Swiatkowski, M. Pakula, S. Biniak, and M. Walczyk, "Influence of the surface chemistry of modified activated carbon on its electrochemical behaviour in the presence of lead(II) ions," Carbon, vol. 42, no. 15, pp. 3057-3069, 2004.

[69] E. S. Hale, K. Hanley, J. Lehmann, A. Zimmerman, and G. Cornelissen, "Effects of chemical, biological, and physical aging as well as soil addition on the sorption of pyrene to activated carbon and biochar," Environmental Science and Technology, vol. 45, no. 24, pp. 10445-10453, 2011.

[70] Y. Gao, Q. Yue, B. Gao et al., "Preparation of high surface areaactivated carbon from lignin of papermaking black liquor by $\mathrm{KOH}$ activation for $\mathrm{Ni}(\mathrm{II})$ adsorption," Chemical Engineering Journal, vol. 217, pp. 345-353, 2013.

[71] B. Zhao and O. D. Nartey, "Characterization and evaluation of biochars derived from agricultural waste biomasses from Gansu, China," in Proceedings of the World Congress on Advances in Civil, Environmental, and Materials Research, Busan, Republic of Korea, 2014.

[72] K. B. Cantrell, P. G. Hunt, M. Uchimiya, J. M. Novak, and K. S. Ro, "Impact of pyrolysis temperature and manure source on physicochemical characteristics of biochar," Bioresource Technology, vol. 107, pp. 419-428, 2012.

[73] J. Harmsen and R. Naidu, "Bioavailability as a tool in site management," Journal of Hazardous Materials, vol. 261, pp. 840846, 2013.

[74] X. D. Cao, L. N. Ma, B. Gao, and W. Harris, "Dairy-manure derived biochar effectively sorbs lead and atrazine," Environmental Science and Technology, vol. 43, pp. 3285-3291, 2009.

[75] D. Kołodyńska, R. Wnętrzak, J. J. Leahy, M. H. B. Hayes, W. Kwapiński, and H. Hubicki, "Kinetic and adsorptive characterization of biochar in metal ions removal," Chemical Engineering Journal, vol. 197, pp. 295-305, 2012.

[76] P. Regmi, J. L. Garcia Moscoso, S. Kumar, X. Cao, J. Mao, and G. Schafran, "Removal of copper and cadmium from aqueous solution using switchgrass biochar produced via hydrothermal carbonization process," Journal of Environmental Management, vol. 109, pp. 61-69, 2012.

[77] B. Singh, B. P. Singh, and A. L. Cowie, "Characterisation and evaluation of biochars for their application as a soil amendment," Australian Journal of Soil Research, vol. 48, no. 6-7, pp. 516-525, 2010.

[78] M. Wu, B. Pan, D. Zhang et al., "The sorption of organic contaminants on biochars derived from sediments with high organic carbon content," Chemosphere, vol. 90, no. 2, pp. 782788, 2013.

[79] X. Cao, L. Ma, B. Gao, and W. Harris, "Dairy-manure derived biochar effectively sorbs lead and atrazine," Environmental Science and Technology, vol. 43, no. 9, pp. 3285-3291, 2009.

[80] N. Kannan and G. Rengasamy, "Comparison of cadmium ion adsorption on various activated carbons," Water, Air, and Soil Pollution, vol. 163, no. 1-4, pp. 185-201, 2005.

[81] O. R. Harvey, B. E. Herbert, R. D. Rhue, and L. Kuo, "Metal interactions at the biochar-water interface: Energetics and structure-sorption relationships elucidated by flow adsorption microcalorimetry," Environmental Science and Technology, vol. 45, no. 13, pp. 5550-5556, 2011.

[82] M. Uchimiya, I. M. Lima, K. T. Klasson, S. Chang, L. H. Wartelle, and J. E. Rodgers, "Immobilization of heavy metal ions (CuII,
CdII, NiII, and PbII) by broiler litter-derived biochars in water and soil," Journal of Agricultural and Food Chemistry, vol. 58, no. 9, pp. 5538-5544, 2010.

[83] B. L. Chen, D. D. Zhou, and L. Z. Zhu, "Transitional adsorption and partition of nonpolar and polar aromatic contaminants by biochars of pine needles with different pyrolytic temperatures," Environmental Science and Technology, vol. 42, no. 14, pp. 51375143,2008

[84] X. Chen, G. Chen, L. Chen et al., "Adsorption of copper and zinc by biochars produced from pyrolysis of hardwood and corn straw in aqueous solution," Bioresource Technology, vol. 102, no. 19, pp. 8877-8884, 2011.

[85] W. Zheng, M. Guo, T. Chow, D. N. Bennett, and N. Rajagopalan, "Sorption properties of greenwaste biochar for two triazine pesticides," Journal of Hazardous Materials, vol. 181, no. 1-3, pp. 121-126, 2010.

[86] M. Uchimiya, L. H. Wartelle, I. M. Lima, and K. T. Klasson, "Sorption of deisopropylatrazine on broiler litter biochars," Journal of Agricultural and Food Chemistry, vol. 58, no. 23, pp. 12350-12356, 2010.

[87] W. H. Huang and B. L. Chen, "Interaction mechanisms of organic contaminants with burned straw ash charcoal," Journal of Environmental Sciences, vol. 22, no. 10, pp. 1586-1594, 2010.

[88] G. Zhang, Q. Zhang, K. Sun, X. Liu, W. Zheng, and Y. Zhao, "Sorption of simazine to corn straw biochars prepared at different pyrolytic temperatures," Environmental Pollution, vol. 159, no. 10, pp. 2594-2601, 2011.

[89] K. Sun, K. Ro, M. Guo, J. Novak, H. Mashayekhi, and B. Xing, "Sorption of bisphenol A, $17 \alpha$-ethinyl estradiol and phenanthrene on thermally and hydrothermally produced biochars," Bioresource Technology, vol. 102, no. 10, pp. 5757-5763, 2011.

[90] R. Xu, S. Xiao, J. Yuan, and A. Zhao, "Adsorption of methyl violet from aqueous solutions by the biochars derived from crop residues," Bioresource Technology, vol. 102, pp. 10293-10298, 2011.

[91] M. Ahmad, S. S. Lee, J. E. Yang, H.-M. Ro, Y. H. Lee, and Y. S. Ok, "Effects of soil dilution and amendments (mussel shell, cow bone, and biochar) on $\mathrm{Pb}$ availability and phytotoxicity in military shooting range soil," Ecotoxicology and Environmental Safety, vol. 79, pp. 225-231, 2012.

[92] G. Marchal, K. E. C. Smith, A. Rein, A. Winding, S. Trapp, and U. G. Karlson, "Comparing the desorption and biodegradation of low concentrations of phenanthrene sorbed to activated carbon, biochar and compost," Chemosphere, vol. 90, no. 6, pp. 1767-1778, 2013.

[93] T. H. Nguyen, H. H. Cho, D. L. Poster, and W. P. Ball, "Evidence for a pore-filling mechanism in the adsorption of aromatic hydrocarbons to a natural wood char," Environmental Science and Technology, vol. 41, pp. 1212-1217, 2007.

[94] Y. Yao, B. Gao, H. Chen et al., "Adsorption of sulfamethoxazole on biochar and its impact on reclaimed water irrigation," Journal of Hazardous Materials, vol. 209-210, pp. 408-413, 2012.

[95] F. Y. Wang, H. Wang, and J. W. Ma, "Adsorption of cadmium (II) ions from aqueous solution by a new low-cost adsorbentBamboo charcoal," Journal of Hazardous Materials, vol. 177, no. 1-3, pp. 300-306, 2010.

[96] B. Wen, R. Li, S. Zhang et al., "Immobilization of pentachlorophenol in soil using carbonaceous material amendments," Environmental Pollution, vol. 157, pp. 968-974, 2006.

[97] J. R. Zimmerman, U. Gosh, R. N. Millward, T. S. Bridges, and R. G. Luthy, "Addition of carbon sorbents to reduce PCB 
and PAH bioavailability in marine sediments: physicochemical tests," Environmental Science and Technology, vol. 38, no. 20, pp. 5458-5464, 2004.

[98] A. Mukherjee and A. R. Zimmerman, "Organic carbon and nutrient release from a range of laboratory-produced biochars and biochar-soil mixtures," Geoderma, vol. 193-194, pp. 122-130, 2013.

[99] L. Lou, L. Luo, G. Cheng et al., "The sorption of pentachlorophenol by aged sediment supplemented with black carbon produced from rice straw and fly ash," Bioresource Technology, vol. 112, pp. 61-66, 2012.

[100] D. Houben, L. Evrard, and P. Sonnet, "Mobility, bioavailability and $\mathrm{pH}$-dependent leaching of cadmium, zinc and lead in a contaminated soil amended with biochar," Chemosphere, vol. 92, no. 11, pp. 1450-1457, 2013.

[101] B. Subramanian, V. Namboodiri, A. P. Khodadoust, and D. D. Dionysiou, "Extraction of pentachlorophenol from soils using environmentally benign lactic acid solutions," Journal of Hazardous Materials, vol. 174, no. 1-3, pp. 263-269, 2010.

[102] M. Inyang, B. Gao, Y. Yao et al., "Removal of heavy metals from aqueous solution by biochars derived from anaerobically digested biomass," Bioresource Technology, vol. 110, pp. 50-56, 2012.

[103] A. H. Rhodes, A. Carlin, and K. T. Semple, "Impact of black carbon in the extraction and mineralization of phenanthrene in soil," Environmental Science and Technology, vol. 42, no. 3, pp. 740-745, 2008.

[104] X. Yu, G. Ying, and R. S. Kookana, "Reduced plant uptake of pesticides with biochar additions to soil," Chemosphere, vol. 76, no. 5, pp. 665-671, 2009.

[105] T. Namgay, B. Singh, and B. P. Singh, "Influence of biochar application to soil on the availability of $\mathrm{As}, \mathrm{Cd}, \mathrm{Cu}, \mathrm{Pb}$, and $\mathrm{Zn}$ to maize (Zea mays L.)," Australian Journal of Soil Research, vol. 48, no. 6-7, pp. 638-647, 2010.

[106] N. Karami, R. Clemente, E. Moreno-Jiménez, N. W. Lepp, and L. Beesley, "Efficiency of green waste compost and biochar soil amendments for reducing lead and copper mobility and uptake to ryegrass," Journal of Hazardous Materials, vol. 191, no. 1-3, pp. 41-48, 2011.

[107] M. J. Denyes, V. S. Langlois, A. Rutter, and B. A. Zeeb, “The use of biochar to reduce soil PCB bioavailability to Cucurbita pepo and Eisenia fetida," Science of the Total Environment, vol. 437, pp. 76-82, 2012.

[108] S. Khan, N. Wang, B. J. Reid, A. Freddo, and C. Cai, "Reduced bioaccumulation of PAHs by Lactuca satuva L. grown in contaminated soil amended with sewage sludge and sewage sludge derived biochar," Environmental Pollution, vol. 175, pp. 64-68, 2013.

[109] J. O. Azeez, S. O. Obanla, A. O. Ojo, and A. O. Shokalu, "Cadmium sorption and desorption characteristics of tropical alfisols from different land uses," Communications in Soil Science and Plant Analysis, vol. 41, no. 1, pp. 108-121, 2010.

[110] G. Cornelissen, G. D. Breedveld, S. Kalaitzidis, K. Christanis, A. Kibsgaard, and A. M. P. Oen, "Strong sorption of native PAHs to pyrogenic and unburned carbonaceous geosorbents in sediments," Environmental Science and Technology, vol. 40, no. 4, pp. 1197-1203, 2006.

[111] Ö. Gustafsson, T. D. Bucheli, Z. Kukulska et al., "Evaluation of a protocol for the quantification of black carbon in sediments," Global Biogeochemical Cycles, vol. 15, no. 4, pp. 881-890, 2001.

[112] R. Cao, L. Lou, T. Xu, D. Duan, and C. Ying, "Effect of bamboo biochar on pentachlorophenol leachability and bioavailability in agricultural soil," Science of the Total Environment, vol. 414, no. 1, pp. 727-731, 2012.

[113] Y. Chun, G. Y. Sheng, G. T. Chiou, and B. Xing, "Compositions and sorptive properties of crop residue-derived chars," Environmental Science and Technology, vol. 38, no. 17, pp. 4649-4655, 2004.

[114] D. Mohan, C. U. Pittman Jr., M. Bricka et al., "Sorption of arsenic, cadmium, and lead by chars produced from fast pyrolysis of wood and bark during bio-oil production," Journal of Colloid and Interface Science, vol. 310, no. 1, pp. 57-73, 2007.

[115] N. Ameloot, S. de Neve, K. Jegajeevagan et al., "Short-term $\mathrm{CO}_{2}$ and $\mathrm{N}_{2} \mathrm{O}$ emissions and microbial properties of biochar amended sandy loam soils," Soil Biology and Biochemistry, vol. 57, pp. 401-410, 2013.

[116] H. J. Cho, K. Baek, J. Jeon, S. H. Park, D. J. Suh, and Y. Park, "Removal characteristics of copper by marine macro-algaederived chars," Chemical Engineering Journal, vol. 217, pp. 205211, 2013.

[117] D. N. Obemah and B. W. Zhao, "Adsorption of $\mathrm{Pb}$ (II) from aqueous solutions onto biochar prepared from cotton residue," Journal of Lanzhou Jiaotong University, vol. 32, pp. 159-169, 2013.

[118] N. Ladygina and F. Rineau, Biochar and Soil Biota, CRS Press, New York, NY, USA, 2013.

[119] Y. Yang, G. Sheng, and M. Huang, "Bioavailability of diuron in soil containing wheat-straw-derived char," Science of the Total Environment, vol. 354, no. 2-3, pp. 170-178, 2006.

[120] J. W. Talley, U. Ghosh, S. G. Tucker, J. S. Furey, and R. G. Luthy, "Particle-scale understanding of the bioavailability of PAHs in sediment," Environmental Science and Technology, vol. 36, no. 3, pp. 477-483, 2002.

[121] U. Ghosh, J. R. Zimmerman, and R. G. Luthy, "PCB and $\mathrm{PAH}$ speciation among particle types in contaminated harbor sediments and effects on PAH bioavailability," Environmental Science and Technology, vol. 37, no. 10, pp. 2209-2217, 2003.

[122] S. K. Nag, R. Kookana, L. Smith, E. Krull, L. M. Macdonald, and G. Gill, "Poor efficacy of herbicides in biochar-amended soils as affected by their chemistry and mode of action," Chemosphere, vol. 84, no. 11, pp. 1572-1577, 2011.

[123] M. T. O. Jonker, M. P. W. Suijkerbuijk, H. Schmitt, and T. L. Sinnige, "Ecotoxicological effects of activated carbon addition to sediments," Environmental Science and Technology, vol. 43, no. 15, pp. 5959-5966, 2009.

[124] S. K. Fagervold, Y. Chai, J. W. Davis, M. Wilken, G. Cornelissen, and U. Ghosh, "Bioaccumulation of polychlorinated dibenzo-pdioxins/dibenzofurans in E. fetida from floodplain soils and the effect of activated carbon amendment," Environmental Science and Technology, vol. 44, no. 14, pp. 5546-5552, 2010.

[125] W. A. W. A. K. Ghani, A. Mohd, G. da Silva et al., "Biochar production from waste rubber-wood-sawdust and its potential use in C sequestration: chemical and physical characterization," Industrial Crops and Products, vol. 44, pp. 18-24, 2013. 

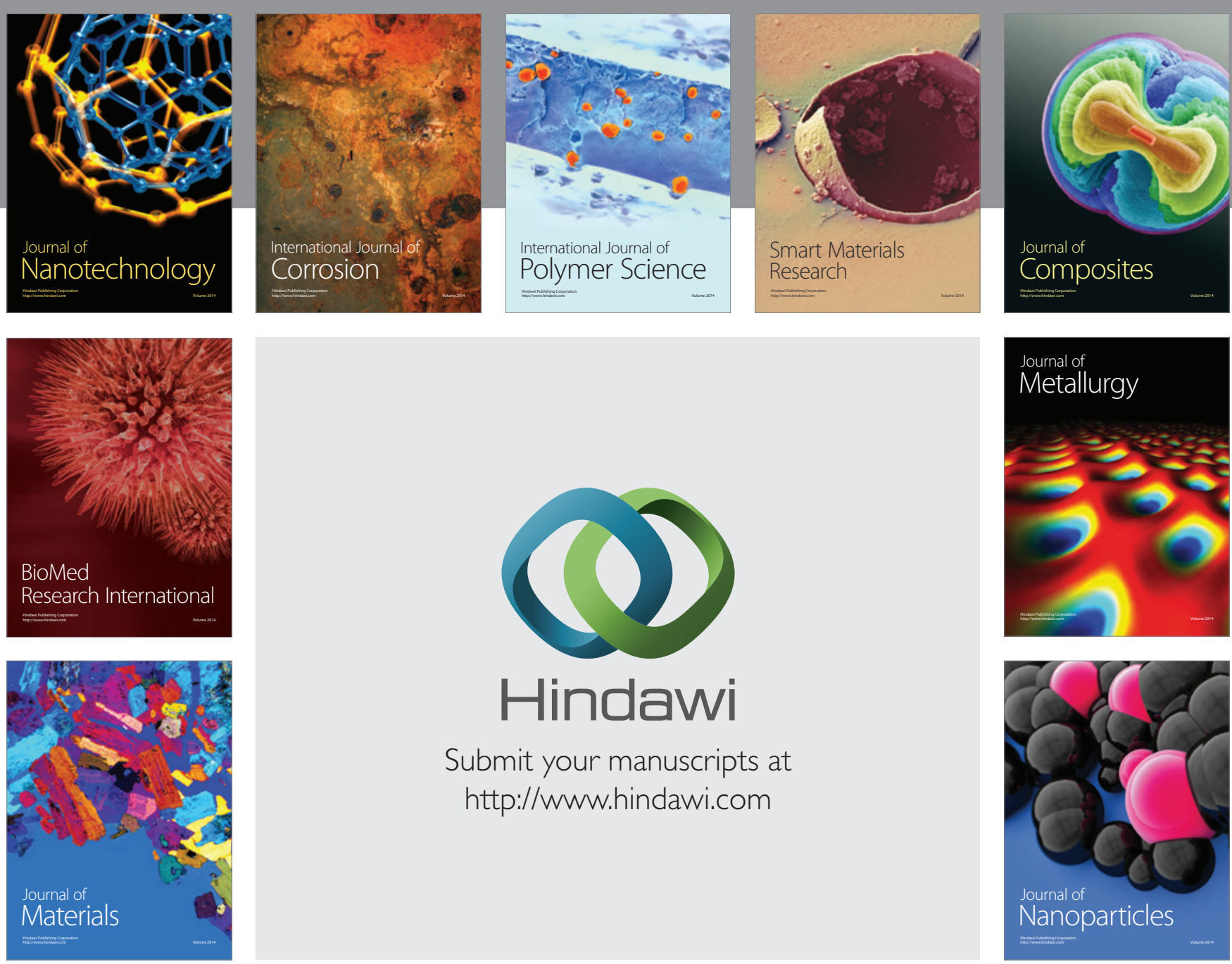

Submit your manuscripts at http://www.hindawi.com
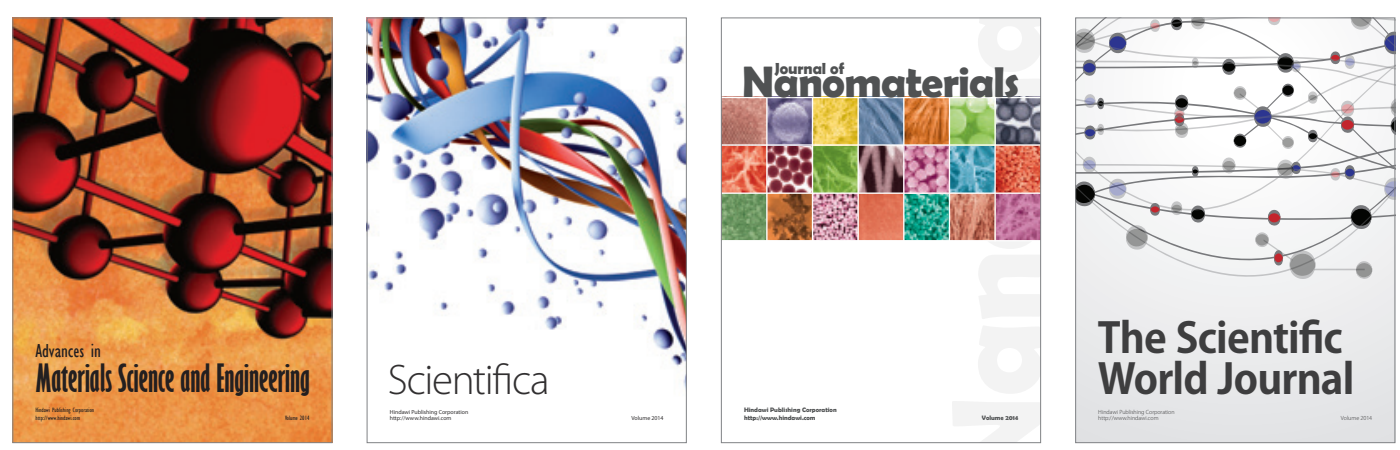

\section{The Scientific World Journal}
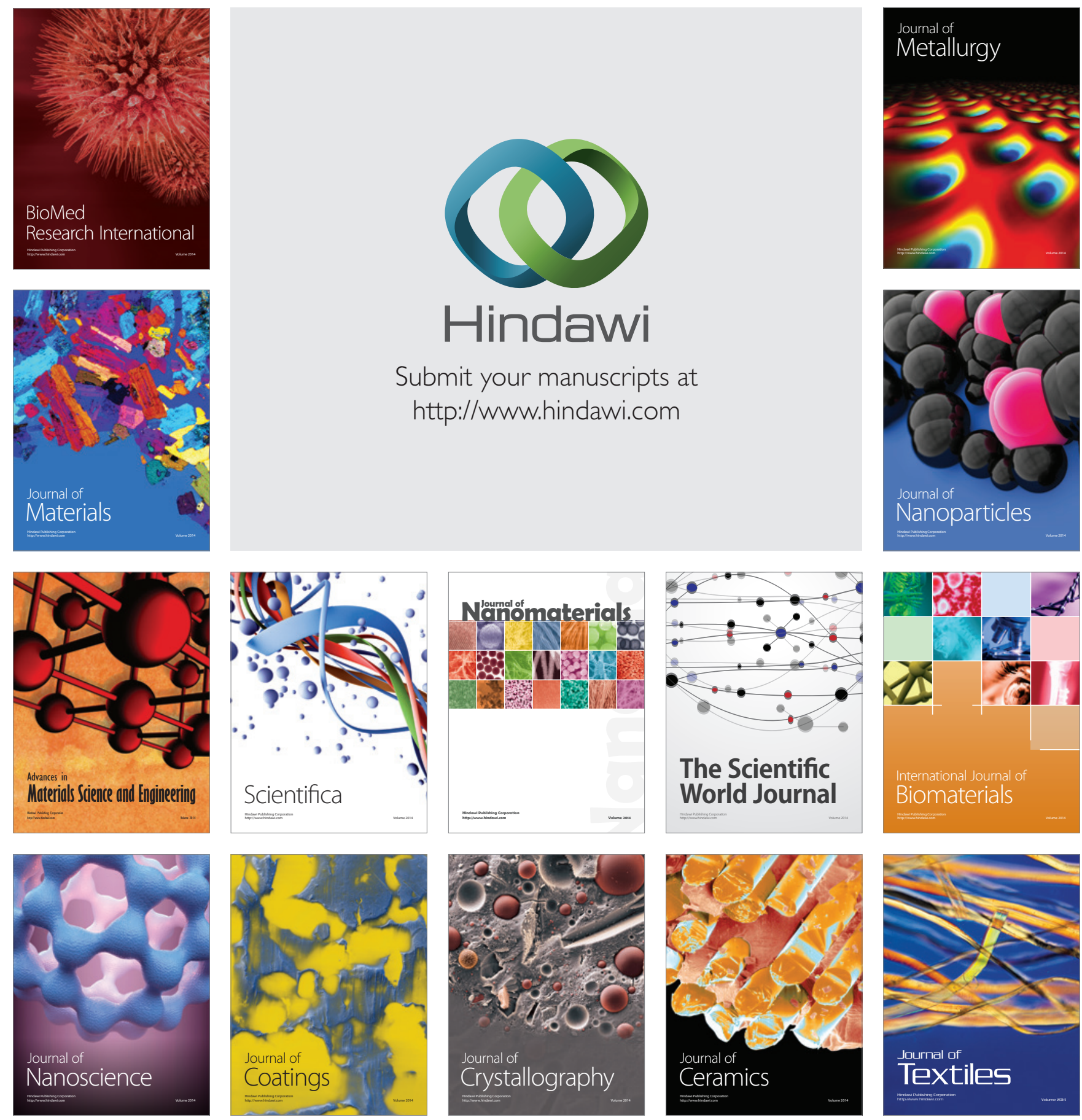